\title{
Forage Production and Water use Efficiency (WUE) of Sorghum (Sorghum Bicolor L.) Under Drought Stress as Affected by Silicon (SI) Treatments
}

\author{
Burhan A. M. Niyazi \\ Department of Hydrology and water resources management, \\ King Abdulaziz University Jeddah, \\ Saudi Arabia
}

\begin{abstract}
This study investigated the role of silicone (Si) in mitigating effects of drought on sorghum (Sorghum bicolor L.) dry forage production and water use efficiency (WUE). Reduction of irrigation water from $100 \%$ to $60 \%$ ETc resulted in significant reduction in dry forage production of sorghum up to $(22.75 \%)$. Reduction in irrigation water from $(100 \%$ to $60 \%$ ETc) increased WUE. Under application of Si forage dry yield and WUE increased significantly. Within each irrigation water level application of $\mathrm{Si}$ resulted in increase in forage dry yield and WUE with increase in Si dose from 0 to $2 \mathrm{~kg} \mathrm{ha-1.} \mathrm{In}$ the meanwhile, the foliar application of $\mathrm{Si}(2 \mathrm{~kg}$ ha-1) with irrigation treatment $(100 \%$ ETc) significantly increased the dry forage yield and raised it to the highest percentage $30 \%$ compared to no $\mathrm{Si}$ treatment. Irrigation with $80 \%$ ETc together with application of $2 \mathrm{~kg}$ ha-1 Si gave the highest WUE compared to $100 \%$ ETc. In growing sorghum for dry yield purpose, $60 \% \mathrm{ETc}$ and $2 \mathrm{~kg}$ ha-1 $\mathrm{Si}$ is an economical option with more water saving and small reduction in yield especially in arid regions.
\end{abstract}

Key words: Sorghum bicoloeL., drought stress, silicon foliar spray

\section{INTRODUCTION}

Sorghum (Sorghum bicolor L.) is one of the best plant crops planted in Saudi Arabia for production of forage, because it grows well in arid land conditions and tolerates water deficient stresses. Drought stress causes 50\% reduction of major crops yield in arid regions as compared to humid and semi-arid regions [4,27]. Sorghum cultivation in Saudi Arabia could be increased to cope with increasing fodder demand of dairy animals by integrated use of some ecofriendly approaches of mitigating drought stress. Silicon (Si) application and proper irrigation scheduling can mitigate drought stress in plants. Researchers have investigated the positive effect of $\mathrm{Si}$ on crop production under drought stress. Silicon ( $\mathrm{Si}$ ) is the second most abundant element in the earth's crust and plays a number of important roles in the mineral nutrition of plants [5]. Calcium silicate is a good source of $\mathrm{Si}$ which is used as fertilizer and some other sources of $\mathrm{Si}$ are silica and calcium silicates [7]. When applied as foliar spray, plants absorb Si by leaves and then the absorbed $\mathrm{Si}$ is redistributed in the leaves and other tissues and plants vary in their ability to absorb Si even in the same species [19].
Si concentration in plants varies from 0.1 to $10 \%$ of dry weight according to genotypes [11]. Si regulates the nutrients uptake in many crops particular under environmental stresses $[25,18]$. In this research study the aim is to examine the effects of silicon $\mathrm{Si}$ in mitigating the sever effects of deficit in irrigation water on the water use efficiency (WUE)and the dry forage production of sorghum under the arid land conditions of Saudi Arabia.

\section{MATERIALS AND METHODS}

The research experiment was conducted in the Research Station of the Faculty of Meteorology, Environment and Arid Land Agriculture at Hada Al-Sham. The design used in this research was split plot design with main plots and subplots with three replications. The experimental area was divided into three main plots and three subplots. The irrigation was applied as main plots and $\mathrm{Si}$ was applied as subplots. The irrigation treatment levels are percentage of crop evapotranspiration's (ETc), and silicon treatments as (0 kg Si ha-1 $1 \mathrm{~kg} \mathrm{Si}$ ha-1, $2 \mathrm{~kg} \mathrm{Si} \mathrm{ha-1} \mathrm{).} \mathrm{Surrounding} \mathrm{the}$ experimental plots, a buffer of two meter $(2 \mathrm{~m})$ wide was also cultivated with the same sorghum crop to make a fetch to reduce uneven weather and wind effects on the experimental plots.

The total number of plots were twenty seven $(3 * 3 * 3=27)$. The dimension of each experimental plot was $(4 \mathrm{~m} \times 2 \mathrm{~m})$ in size with one meter clearance between each plot to prevent inter-plot water flow. The experimental area was irrigated then ploughed twice, and levelled.

\footnotetext{
Plots irrigation system

Four plastic tanks (6000 litters capacity of each) were installed, interconnected and connected with irrigation pump. Bubbler irrigation system was used. Each plot was provided with eight bubblers of Rain Bird pressure compensating full circle trickle pattern 0.5 GPM discharge. The bubblers within each plot were mounted on two Poly Ethylene (PE) laterals pipelines of one inch size at one meter spacing. The bubblers were mounted using saddle of 1 inch* $1 / 2$ inch size (female threads) and six inch long PE risers. Each bubbler had builtin strainer to filter course sand and debris. Each PE lateral line supplied irrigation to three sub-plots running from east
} 
to west by applying same irrigation amount. The main and sub-main lines used were two inch PE pipe running from north to south outside the plots (flowmeter). Electrical pressure control valve was used at delivery of pump to deliver even pressure and prevent damage to the pump or lines while keeping bubblers' discharge constant. Flow rate was measured with seven bubblers in each plot and larger capacity pump and found to be very close to the standard discharge with small variation. Four pressure gauges were installed to check the operating pressure at pump, in the main line, in the sub main lines and in the laterals lines.

\section{Method used in irrigation}

The water balance irrigation scheduling method involves estimation of the soil water balance by measuring the amount of rainfall, irrigation and then estimating the soil water depletion by calculating water consumed by the crop. It is a flexible method and can forecast irrigation needs in future depending upon weather forecast. The procedure of water balance irrigation scheduling is as follows:

$\mathrm{AWSC}=\mathrm{FC}-\mathrm{PWP}$

Where

AWSC: is the available water storage capacity of the soil $(\mathrm{mm} / \mathrm{m})$.

FC: is the field capacity (volumetric moister content (\%) (Upper limit).

PWP: is the permanent wilting point (volumetric moister content $(\%) \quad$ (Lower limit).

Evapotranspiration (ET) is the combination of two separate processes (Evaporation and Transpiration) whereby water is lost from the soil surface by evaporation and from the crops by transpiration.

\section{Planting of sorghum}

Sorghum fodder local variety Jizani was sown. Sorghum seeds were sown manually in all plots after preparation of irrigation system and levelling. Spacing between rows kept at $30 \mathrm{~cm}$. Six rows were sown in each plot. Six rows were also sown as buffer area at the same time. Seed rate of $60 \mathrm{~kg} / \mathrm{ha}$ was used. The crop was sown on 13th March 2017 and the 3 rd cut was harvested on 30th September 2017. The duration of 1st cut was 61 days (Sowing date 13th March and Harvesting date 13th May).

\section{Application of silicon treatments}

Irrigation and $\mathrm{Si}$ treatments were applied after proper germination and crop establishment period at five leaves stage. Foliar application of $\mathrm{Si}$ was at the rate of $(1 \mathrm{~kg} / \mathrm{ha}=0.1$ $\mathrm{gram} / \mathrm{m} 2$ and $2 \mathrm{~kg} / \mathrm{ha}=0.2 \mathrm{gram} / \mathrm{m} 2$ ).

\section{RESULTS}

Analysis of variance (ANOVA) for WUE and dry forage yield of sorghum during growing season 2017.

The analysis of variance (Table 1) indicated that the effects of irrigation treatments $((100 \%, 80 \%$ and $60 \% \mathrm{ETc})$ and $\mathrm{Si}$ foliar applications ( 1 and $2 \mathrm{~kg} / \mathrm{ha}$ ) were highly significantly different in results of the studied parameters (water use efficiency WUE and total dry forage yield of sorghum) at ( $\mathrm{P} \leq$ $0.01)$ during all cuts. Also there are significant differences between treatments as regards interaction between irrigation and silicon (irr. X Si). 
TABLE 1. THE ANALYSIS OF VARIANCE FOR WATER USE EFFICIENCY (IWUE) AND DRY FORAGE YIELD, OF SORGHUM CROP UNDER THE EFFECT OF IRRIGATION AND SILICON TREATMENTS AND THEIR INTERACTION DURING.

\begin{tabular}{|c|c|c|c|c|}
\hline \multirow{7}{*}{ 1st Cut } & Source of variance & df & $\begin{array}{l}\text { Irrigation water use efficiency } \\
(\mathrm{kg} / \mathrm{m} 3 / \mathrm{ha})\end{array}$ & $\begin{array}{c}\text { Dry forage yield } \\
\text { (t/ha) }\end{array}$ \\
\hline & Replication & 2 & $0.63 \mathrm{NS}$ & $2.03 \mathrm{NS}$ \\
\hline & Irrigation(Irri) & 2 & $5.81 * *$ & $19.30 * *$ \\
\hline & Error (a) & 4 & 0.14 & 0.18 \\
\hline & Silicon $(\mathrm{Si})$ & 2 & $43.90 * *$ & $24.10 * *$ \\
\hline & Irri* Si & 4 & $1.20 * *$ & $0.69 *$ \\
\hline & Error (b) & 12 & 0.138 & 0.136 \\
\hline \multirow{6}{*}{ 2nd cut } & Replication & 2 & $0.19 \mathrm{NS}$ & $1.66 \mathrm{NS}$ \\
\hline & Irrigation(Irri) & 2 & $0.53 *$ & $14.89 * *$ \\
\hline & Error (a) & 4 & 0.05 & 0.18 \\
\hline & Silicon (Si) & 2 & $16.08 * *$ & $18.48 * *$ \\
\hline & Irri* Si & 4 & $0.31 *$ & $0.46^{* * *}$ \\
\hline & Error (b) & 12 & 0.62 & 0.117 \\
\hline \multirow{6}{*}{ 3rd cut } & Replication & 2 & $0.69 \mathrm{NS}$ & $1.98 \mathrm{NS}$ \\
\hline & Irrigation(Irri) & 2 & $15.39 * *$ & $17.66 * *$ \\
\hline & Error (a) & 4 & 0.21 & 0.21 \\
\hline & Silicon $(\mathrm{Si})$ & 2 & $58.89 * *$ & $21.96 * *$ \\
\hline & Irri* $\mathrm{Si}$ & 4 & $1.86 * *$ & $0.55^{*}$ \\
\hline & Error & 12 & 0.223 & 0.138 \\
\hline
\end{tabular}

Ns: not significant at $(\mathrm{P} \leq 0.05)$. ${ }^{*}$ : Significant at $(\mathrm{P} \leq 0.05)$. **: significant at $(\mathrm{P} \leq 0.01)$.

Effect of irrigation and Si levels on water use efficiency (WUE) of sorghum crop

\section{Analysis of variance}

Table (1) illustrates that there were significant differences between both different water levels and different $\mathrm{Si}$ concentrations and their interactions on the WUE during all cuts.
Means comparisons of irrigation water use efficiency of Sorghum crop

During 1st cut the decrease in irrigation amount from $100 \%$ to $60 \%$ ETc increased water use efficiency from 15.26 $\mathrm{kg} / \mathrm{m} 3 / \mathrm{ha}$ to $16.63 \mathrm{~kg} / \mathrm{m} 3 / \mathrm{ha}$ and during the third cut from 17.37 to $19.87 \mathrm{~kg} / \mathrm{m} 3 / \mathrm{ha}$, while under application of $\mathrm{Si}$ at levels from 0 to $2 \mathrm{~kg} / \mathrm{ha}$ the WUE increased from 13.70 to $18.07 \mathrm{~kg} / \mathrm{m} 3 / \mathrm{ha}$ during the $1 \mathrm{st}$ cut and from 8.41 to 11.06 $\mathrm{kg} / \mathrm{m} 3 / \mathrm{ha}$ during the $2 \mathrm{nd}$ cut and from 15.95 to 21.01 $\mathrm{kg} / \mathrm{m} 3 / \mathrm{ha}$ during the $3 \mathrm{rd}$ cut. (Table 2 ).

TABLE 2. MEANS OF IRRIGATION WATER USE EFFICIENCY (KG/M3/HA) OF SORGHUM CROP UNDER THE EFFECT OF VARYING LEVELS OF IRRIGATION AND SILICON DURING 2017 CROP SEASON.

\begin{tabular}{|l|c|c|c|}
\hline \multirow{2}{*}{ Treatments levels } & \multicolumn{3}{|c|}{ Number of cuts of Sorghum crop } \\
\cline { 2 - 4 } & 2st cut cut & 3rd cut \\
\hline Irrigation levels (\% ETc) & \multicolumn{3}{|c|}{} \\
\hline $\mathbf{1 0 0}$ & $15.26 \mathrm{~b}$ & $9.87 \mathrm{a}$ & $17.37 \mathrm{~b}$ \\
\hline $\mathbf{8 0}$ & $15.22 \mathrm{~b}$ & $9.39 \mathrm{~b}$ & $17.69 \mathrm{~b}$ \\
\hline $\mathbf{6 0}$ & $16.63 \mathrm{a}$ & $9.64 \mathrm{ab}$ & $19.78 \mathrm{a}$ \\
\hline LSD (0.05) & 0.506 & 0.317 & 0.606 \\
\hline Silicon levels (kg/ha) & & $8.41 \mathrm{c}$ & $15.95 \mathrm{c}$ \\
\hline $\mathbf{0}$ & $13.70 \mathrm{c}$ & $9.42 \mathrm{~b}$ & $17.87 \mathrm{~b}$ \\
\hline $\mathbf{1}$ & $15.35 \mathrm{~b}$ & $11.06 \mathrm{a}$ & $21.01 \mathrm{a}$ \\
\hline $\mathbf{2}$ & $18.07 \mathrm{a}$ & 0.256 & 0.485 \\
\hline LSD (0.05) & 0.382 & & \\
\hline
\end{tabular}

Interaction effect of irrigation and Si on irrigation water use efficiency of Sorghum crop

Interaction between irrigation and $\mathrm{Si}$ treatments means (Table 3, Fig. 1) showed that water use efficiency increased within same irrigation levels, with increase in Si dose from 0 to $2 \mathrm{~kg}$ Si ha-1 during all cuts. And the decrease in irrigation levels (increase drought stress) also increased the water use efficiency compared with control. The overall trend in water use efficiency followed the pattern that it was more during 1 st cut then decreased during 2nd cut and also increased during 3rd cut. WUE values under Si treatment ( $2 \mathrm{~kg}$ Si ha1) and irrigation treatment $(60 \% \mathrm{ETc})$ were maximum during all cuts, compared with controls. 
TABLE 3. EFFECT OF INTERACTION BETWEEN IRRIGATION AND SI LEVELS ON MEANS OF IRRIGATION WATER USE EFFICIENCY (KG/M3/HA) OF SORGHUM CROP DURING 2017 CROP SEASON.

\begin{tabular}{|c|c|c|c|c|}
\hline \multirow{6}{*}{ 1st Cut } & \multirow[t]{2}{*}{ Irrigation levels (\% of ETc) } & \multicolumn{3}{|c|}{ Silicon levels (kg/ha) } \\
\hline & & 0 & 1 & 2 \\
\hline & 100 & \multirow{3}{*}{$\begin{array}{l}13.44 \\
13.94\end{array}$} & \multirow{3}{*}{$\begin{array}{l}14.91 \\
16.25\end{array}$} & \multirow{3}{*}{$\begin{array}{l}17.44 \\
19.72\end{array}$} \\
\hline & 80 & & & \\
\hline & 60 & & & \\
\hline & $\operatorname{LSD}(0.05)$ & \multicolumn{3}{|c|}{0.66} \\
\hline \multirow{6}{*}{ 2nd Cut } & \multirow[t]{2}{*}{ Irrigation levels (\% of ETc) } & \multicolumn{3}{|c|}{ Silicon levels $(\mathrm{kg} / \mathrm{h} \mathrm{a})$} \\
\hline & & 0 & 1 & 2 \\
\hline & 100 & \multirow{3}{*}{$\begin{array}{l}8.72 \\
8.07\end{array}$} & \multirow{3}{*}{$\begin{array}{l}9.63 \\
9.45\end{array}$} & \multirow{3}{*}{$\begin{array}{l}11.27 \\
11.41\end{array}$} \\
\hline & 80 & & & \\
\hline & 60 & & & \\
\hline & LSD (0.05) & \multicolumn{3}{|c|}{0.44} \\
\hline \multirow{6}{*}{ 3rd Cut } & \multirow[t]{2}{*}{ Irrigation levels (\% of ETc) } & \multicolumn{3}{|c|}{ Silicon levels $(\mathrm{kg} / \mathrm{h} \mathrm{a})$} \\
\hline & & 0 & 1 & 2 \\
\hline & 100 & \multirow{3}{*}{$\begin{array}{l}15.34 \\
16.55\end{array}$} & \multirow{3}{*}{$\begin{array}{l}16.94 \\
19.38\end{array}$} & \multirow{3}{*}{$\begin{array}{l}19.82 \\
23.40\end{array}$} \\
\hline & 80 & & & \\
\hline & 60 & & & \\
\hline & $\operatorname{LSD}(0.05)$ & \multicolumn{3}{|c|}{0.84} \\
\hline
\end{tabular}

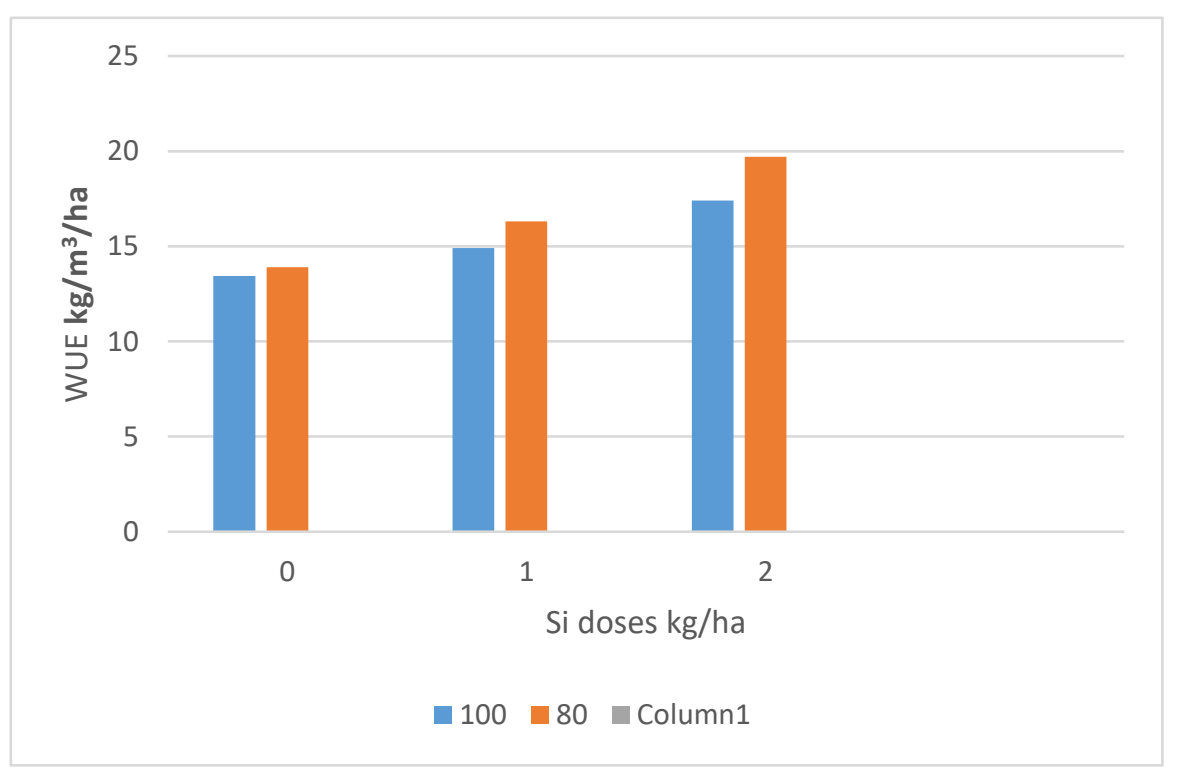

FIG.1. INTERACTION BETWEEN IRRIGATION AND SI LEVELS ON WATER USE EFFICIENCY (KG/M3/HA) OF SORGHUM CROP DURING 1ST.

Effect of irrigation and Si levels on dry forage yield of sorghum crop:

Means comparisons of dry forage yield of Sorghum crop:

The decrease in irrigation from $100 \%$ to $60 \%$ of ETc reduced the dry forage yield of sorghum from $15.32 \mathrm{t} / \mathrm{ha}$ to $12.48 \mathrm{t} / \mathrm{ha}$ $(18.53 \%)$ during $1 \mathrm{st}$ cut, from $13.79 \mathrm{t} / \mathrm{h}$ to $11.30 \mathrm{t} / \mathrm{ha}$ (18.22\%) during 2nd cut and from 15.03 t/ha to $12.32 \mathrm{t} / \mathrm{ha}$ $(18.03 \%)$ during 3rd cut, and under application of Si from 0$2 \mathrm{~kg} / \mathrm{ha}$ sorghum forage dry yield increased from $12.19 \mathrm{t} / \mathrm{ha}$ to $15.44 \mathrm{t} / \mathrm{ha}(21.04 \%)$, from $11.06 \mathrm{t} / \mathrm{ha}$ to $13.90 \mathrm{t} / \mathrm{ha}$ $(20.43 \%)$, and from $12.06 \mathrm{t} /$ ha to $15.15 \mathrm{t} / \mathrm{ha}(20.39 \%)$ during the 1 st, 2 nd and 3rd cut respectively (Table 4).

Interaction effect of irrigation and Si levels on dry forage yield of Sorghum crop:
The interaction of irrigation and Si levels was also significant $(\mathrm{P} \leq 0.05)$ during $1 \mathrm{st}$ and $3 \mathrm{rd}$ cuts while it was highly significant $(\mathrm{P} \leq 0.01)$ during 2nd cut. Means of Interaction between irrigation and $\mathrm{Si}$ treatments (Table 5 and Fig. 2) showed that within same irrigation level dry forage yield increased with increase in Si rate, and within each Si dose dry forage yield decreased with decrease in irrigation levels (increase drought stress) compared with. For the 1st cut, the maximum dry forage yield was $17.03(\mathrm{t} / \mathrm{ha})$, while it was $15.31(\mathrm{t} / \mathrm{ha})$ for the 2 nd cut and $16.70(\mathrm{t} / \mathrm{ha}$ ) for the $3 \mathrm{rd}$ one. The dry forage yield was more during 1 st cut then decreased during 2 nd cut and also increased during 3rd cut. During 2nd cut under severe drought stress the dry yield was less affected as compared to other studied crop parameters. Under Si treatment two (2 $\mathrm{kg} \mathrm{Si} \mathrm{ha-1)} \mathrm{and} \mathrm{irrigation} \mathrm{treatment} \mathrm{two}$ $(60 \%$ ETc) the yield was $14.77(\mathrm{t} / \mathrm{ha})$ In the 1 st cut, 13.28 ( $t /$ ha) for the 2nd and 14.47 (t/ha) for the 3rd cut. 
TABLE 4. MEANS OF DRY FORAGE YIELD (T/HA) OF SORGHUM UNDER THE EFFECT OF VARYING LEVELS OF IRRIGATION AND SILICON DURING 2017 CROP SEASON. NUMBER OF CUTS OF SORGHUM CROP

\begin{tabular}{|c|c|c|c|}
\hline \multirow[t]{2}{*}{ Treatments levels } & \multicolumn{3}{|c|}{ Number of cuts of Sorghum crop } \\
\hline & 1st cut & 2nd cut & 3rd cut \\
\hline \multicolumn{4}{|l|}{ Irrigation levels (\% ETc) } \\
\hline 100 & $15.32 \mathrm{a}$ & $13.79 \mathrm{a}$ & $15.03 \mathrm{a}$ \\
\hline 80 & $13.29 \mathrm{~b}$ & $11.97 \mathrm{~b}$ & $13.05 \mathrm{~b}$ \\
\hline 60 & $12.48 \mathrm{c}$ & $11.30 \mathrm{c}$ & $12.32 \mathrm{c}$ \\
\hline LSD (0.05) & 0.378 & 0.35 & 0.38 \\
\hline \multicolumn{4}{|l|}{ Silicon levels (kg/ha) } \\
\hline $\mathbf{0}$ & $12.19 \mathrm{c}$ & $11.6 \mathrm{c}$ & $12.06 \mathrm{c}$ \\
\hline 1 & $13.46 \mathrm{~b}$ & $12.11 \mathrm{~b}$ & 13.20 \\
\hline 2 & $15.44 \mathrm{a}$ & $13.90 \mathrm{a} \mathrm{b}$ & $15.15 \mathrm{a}$ \\
\hline LSD (0.05) & 0.378 & 0.35 & 0.38 \\
\hline
\end{tabular}

TABLE 5: EFFECT OF INTERACTION BETWEEN IRRIGATION AND SI LEVELS ON MEANS OF DRY FORAGE YIELD (T/HA) OF SORGHUM CROP DURING 2017 CROP SEASON.

\begin{tabular}{|c|c|c|c|c|}
\hline \multirow[t]{6}{*}{ 1st Cut } & \multirow{2}{*}{$\begin{array}{c}\text { Irrigation levels (\% } \\
\text { ETc) }\end{array}$} & \multicolumn{3}{|c|}{ Silicon levels (kg/ha) } \\
\hline & & $\mathbf{0}$ & 1 & 2 \\
\hline & 100 & 13.83 & 15.13 & 17.01 \\
\hline & 80 & 12.24 & 13.06 & 14.56 \\
\hline & 60 & 10.51 & 12.18 & 14.75 \\
\hline & $\operatorname{LSD}(0.05)$ & & 0.65 & \\
\hline \multirow[t]{6}{*}{ 2nd Cut } & Irrigation levels (\% ETc) & \multicolumn{3}{|c|}{ Silicon levels (kg/ha) } \\
\hline & & 0 & 1 & 2 \\
\hline & 100 & 12.45 & 13.62 & 15.31 \\
\hline & 80 & 11.06 & 11.76 & 13.11 \\
\hline & 60 & 9.68 & 13.28 & 13.28 \\
\hline & $\operatorname{LSD}(0.05)$ & & 0.61 & \\
\hline \multirow[t]{6}{*}{ 3rd Cut } & Irrigation levels (\% ETc) & \multicolumn{3}{|c|}{ Silicon levels (kg/ha) } \\
\hline & & 0 & 1 & 2 \\
\hline & 100 & 13.57 & 14.84 & 16.70 \\
\hline & 80 & 12.07 & 12.81 & 14.29 \\
\hline & 60 & 10.55 & 11.95 & 14.47 \\
\hline & $\operatorname{LSD}(0.05)$ & & 0.66 & \\
\hline
\end{tabular}

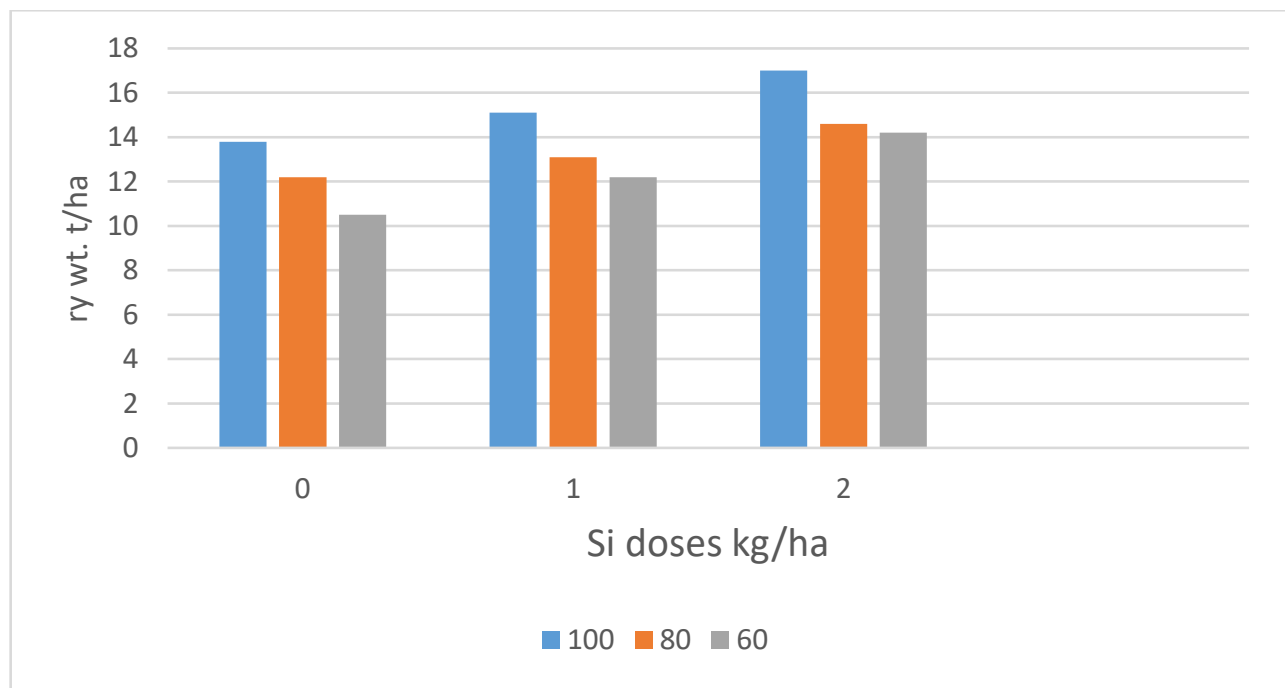

FIG. 2. INTERACTION BETWEEN IRRIGATION AND SI LEVELS ON WATER USE EFFICIENCY (KG/M3/HA) OF SORGHUM CROP DURING $1 \mathrm{ST}$. 


\section{DISCUSSION}

In spite of the limited studies on the interaction of drought and application of silicone (Si) as mitigating factor improving irrigation water use efficiency (WUE) in soils and enhancing crop growth yields some researchers obtained good results in this field [14,21]. The results showed that drought effects under reduction of irrigation water from $100 \%$ to $60 \%$ particularly during 2 nd cut decreased sorghum plant forage dry yield up to (23\%), and increased WUE up to $6.6 \%$. Drought stress is one of the most important abiotic stress factor that affects plant growth specially in arid and semi-arid regions all over the world $[26,12,16]$. Significant reductions have been observed in morphological, physiological and metabolic parameters of plants under drought stress [20]. Growth rate of crop plants suffered reduction under drought stress $[2,3,15,23]$. The increase in sorghum dry forage yield and in WUE under application of $\mathrm{Si}$ in this study probably might have been due to seepage of $\mathrm{Si}$ into the plant tissues reaching the roots, enhancing their growth enabling them to absorb more water from soil thus result in increase in dry forage yield and WUE. These results agree with previous studies on effect of $\mathrm{Si}$ under drought stress particularly on sorghum as was documented by $[9,17]$. Number of researchers applied Si under drought stresses and found improvement in crop yield and crop quality $[13,22,24,6,8,10]$, working on wheat growth and [1] on sorghum found increases in plant height, dry matter, chlorophyll content, relative water content, stomatal conductance in wheat and sorghum plants when treated with Si under drought stress. Our data suggest that the combined use of Si under irrigation water stress is an effective approach for improving dry forage yield in Sorghum water use efficiency on marginal land.

\section{CONCLUSION}

The decrease in irrigation water from (100\% to $60 \%$ ETc) (about $25 \%$ water saving) without $\mathrm{Si}$ application, resulted in a decrease in sorghum forage dry yield $(22.75 \%)$ during all cuts. On the other hand reduction in irrigation water from (100\% to $60 \%$ ETc) resulted in increase in WUE. Within each irrigation water level application of $\mathrm{Si}$ resulted in increase in forage dry yield and WUE with increase in Si dose from 0 to $2 \mathrm{~kg}$ ha- 1 . In the meanwhile, the foliar application of $\mathrm{Si}$ (2 kg ha-1) with irrigation treatment (100\% ETc) significantly increased the dry forage yield by $30 \%$ compared to no Si treatment. This may be due to the improvement in the growth promoting factors initiated by application of $\mathrm{Si}$ represented in improved WUE and increased root volume under these drought stress conditions.

Using the yield per unit water used, the $2 \mathrm{~kg}$ ha- 1 Si treatment was the best as it reached $17-23 \mathrm{~kg} / \mathrm{ha} . \mathrm{mm}$ while it was between 13 and $17 \mathrm{~kg} / \mathrm{ha} . \mathrm{mm}$ excluding the second cut that has least effect. In growing sorghum for dry yield purpose, $60 \%$ ETc and $2 \mathrm{~kg}$ ha- $1 \mathrm{Si}$ is an economical option with more water saving and small reduction in yield especially in arid regions.

\section{REFERENCES}

[1] A. A. Ahmed, M. M. Selim, A. A. Alderfasi and M. Afzal. "Effect of drought stress on mungbean (Vigna radiata L.) under arid climatic conditions of Saudi“. Miralles i Garcia, JL and Brebbia, CA (eds.) Ecosysten and Sustainable Development. WIT Press, Southampton, UK, 185-193.

[2] F. Anjum, Yaseen, M. Rasul, E. Wahid, A and S. Anjum. "Water stress in barley (Hordeum vulgare L.). Effect on morphological characters". Pak. J. Agric. Sci, 40: 43-44. 2003a

[3] R. M. Bhatt and N. K. S. Rao. "Influence of pod load response of okra to water stress“. Ind. J. Plant Physiol., 10: 54-59. 2005

[4] M. M. Chaves J. P. Maroco and J. S. Pereira. "Understanding plant responses to drought-from genes to the whole plant". Funct. Plant Biol. 30: 239-264. 2003

[5] L. E. Datnoff, G. H. Snyder and G. H. Korndorfer. "Silicon in agriculture. ISBN: 9780444502629. Studies in Plant Science 8“. Elsevier science, Amsterdam USA. 8(1): 1-424. 2001.

[6] A. E. Eneji, S. Inanaga, S. Muranaka, J. Li, T. Hattori, P. A and W. Tsuji. "Growth and nutrient use in four grasses under drought stress as mediated by silicon fertilizers". J. Plant Nutr, 31: 355-365. 2008

[7] G. J. Gascho. "Silicon sources for agriculture. In: Datnoff L. E, Snyder G. H, Korndorfer G. H (eds) Silicon in agriculture". Studies in plant science, 8. Elsevier, Amsterdam. pp. 197-207. 2001.

[8] H. J. Gong, K. M. Chen, G. C. Chen, S. M. Wang and C. L. Zhang. "Effects of silicon on growth of wheat under drought". J. Plant Nutr, 26: 1055-1063. 2003.

[9] F. Guntzer, C. Keller and J. D. Meunier. "Benefits of plant silicon for crops: a review“. Agron. Sustain. Dev., 32: 201- 213. 2012.

[10] T. Hattori, H. Inanaga, H. Araki, P., S. Morita, M. Luxova and A Lux. "Application of silicon enhanced drought tolerance in Sorghum bicolor". Plant Physiol, 123: 459-466.2005.

[11] M. J. Hodson, P. J. White, A. Mead and M. R. Broadley. "Phylogenetic variation in the silicon composition of plants". Annu. Bot, 96: 1027-1046. 2005.

[12] A. Hossain, M. A .Z. Sarker, M. Saifuzzaman, J.A. Silva, M. V Lozovskaya and M. M. Akhter. "Evaluation of growth, yield, relative performance and heat susceptibility of eight wheat (Triticum aestivum L.) genotypes grown under heat stress“. Int. J. Plant Prod, 7: 615-636. 2013.

[13] C. Kaya, L. Tuna and D. Higgs. "Effect of silicon on plant growth and mineral nutrition of maize grown under water-stress conditions“. J. Plant Nutr. 29: 1469-1480. 2006

[14] Y.H. Kim, A.L. Khan Waqas, M. Shim, J.K. Kim, D.H. Lee, K.Y and I.J. Lee. "Silicon Application to Rice Root Zone Influenced the Phytohormonal and Antioxidant Responses under Salinity Stress“. J. Plant Growth Regul. 33: 137-149. 2014a.

[15] M. Kusaka, M. Ohta and T. Fujimura. "Contribution of inorganic components to osmotic adjustment and leaf folding for drought tolerance in pearl millet“. Plant Physiol, 125: 474-489. 2005.

[16] J. Lipiec, C. Doussan, A. Nosalewicz and K. Kondracka. "Effect of drought and heat stresses on plant growth and yield": a review. Int J. Agrophys., 27: 463-477. 2016.

[17] A., Lux, M. Luxova, T. Hattori, S. Inanaga and Y. Sugimoto. “ Silicification in sorghum (Sorghum bicolor) cultivars with different drought tolerance“. Plant Physiol., 115: 87-92. 2002.

[18] J. F. Ma, E. Takahashi. "Soil, Fertilizer, and Plant Silicon Research in Japan. Elsevier Science, Amsterdam, The Neitherland. 2002.

[19] J. F. Ma, S. Goto, K. Tamai and M. Ichii. "Role of root hairs and lateral roots in silicon uptake by rice". Plant Physiol., 127: 1773 1780. 2001.

[20] M. Maqsood, M. A. Shehzad, S. Ahmad and S. Mushtaq "Performance of wheat (Triticum aestivum L.) Genotypes associated with agronomical traits under water stress conditions". Asian J. Pharm. Biol. Res., 2: 45-50. 2012.

[21] R. Martínez, Espejo, A., Sierra, M., Ortiz-Bernad, I., Correa, D., Bedmar, E., LópezJurado, M. and Porres, J.M. "Co-inoculation of Halomonas maura and Ensifer meliloti to improve alfalfa yield in saline soils". App. Soil Ecol. 87: 81-86. 2015

[22] Z. F. Pei, D. F. Ming, D. Liu, G. L. Wan, X. X. Geng, H. J. Gong and W. J. Zhou. "Silicon improves the tolerance of water-deficit stress induced by polyethylene glycol in wheat (Triticum aestivum L.) seedlings". J. Plant Growth Reg, 29: 106 -115. 2010. 
[23] H. B. Shao, L. Y. Chu, M. A. Shao, C. A. Jaleel and M. Hong-Mei. "Higher plant antioxidants and redox signaling under environmental stresses." Comp. Rend. Biol, 331: 433-441. 2008.

[24] X. Shen, Y. Zhou, L. Duan, A. E. Eneji and J. Li.” Silicon effects on photosynthesis and antioxidant parameters of soybean seedlings under drought and ultraviolet-B radiation”. J. Plant Physiol., 167: $1248-1252.2010$
[25] A. Wallace. "Participation of silicon in cation-anion balance as a possible mechanism for aluminum and iron tolerance in some Gramineae". J. Plant Nutr, 16: 547-553. 1993.

[26] Z. G. Zalibekov. "The arid regions of the world and their dynamics in conditions of modern climatic warming". Arid Ecosys., 1: 1-7. 2011.

[27] Z. Zlatev and F. C. Lidon. "An overview on drought induced changes in plant growth, water relations and photosynthesis". Emir. J. Food Agr. 24: 57-72. 2012. 